\section{OPEN ACCESS}

Edited by:

Georgios Daletos,

Heinrich-Heine-Universität Düsseldorf,

Germany

Reviewed by:

Joachim Wink,

Helmholtz Center for Infection Research, Helmholtz Association of German Research Centres (HZ),

Germany

Paula Branquinho Andrade, Universidade do Porto, Portugal

*Correspondence:

Olga M. Lage olga.lage@fc.up.pt

Specialty section: This article was submitted to

Marine Biotechnology,

a section of the journal

Frontiers in Marine Science

Received: 19 April 2018

Accepted: 11 December 2018

Published: 07 January 2019

Citation:

Calisto R, Sæbø EF,

Storesund JE, Øvreås L, Herfindal L and Lage OM (2019) Anticancer

Activity in Planctomycetes.

Front. Mar. Sci. 5:499.

doi: 10.3389/fmars.2018.00499

\title{
Anticancer Activity in Planctomycetes
}

\section{Rita Calisto 1,2, Eirik Færøy Sæbø ${ }^{3}$, Julia E. Storesund ${ }^{3}$, Lise Øvreås ${ }^{3,4}$, Lars Herfindal ${ }^{5}$ and Olga M. Lage ${ }^{1,2 *}$}

\begin{abstract}
${ }^{1}$ Department of Biology, Faculty of Sciences, University of Porto, Porto, Portugal, ${ }^{2}$ Interdisciplinary Centre of Marine and Environmental Research, University of Porto, Porto, Portugal, ${ }^{3}$ Department of Biological Sciences, University of Bergen, Bergen, Norway, ${ }^{4}$ Department of Arctic Biology, University Centre in Svalbard, Longyearbyen, Norway, ${ }^{5}$ Centre for Pharmacy, Department of Clinical Science, University of Bergen, Bergen, Norway
\end{abstract}

There is a strong need to develop new drugs against many severe diseases. Therapy resistance is a major problem, for instance, in infectious diseases and cancer. Drug discovery has again turned to nature to search for molecules that can become drug leads. Although many bacterial phyla are extensively studied, some, like the Planctomycetes, remain largely unexplored as potential sources of new leads. Planctomycetes form a diverse group of bacteria with peculiar characteristics such as division by polar budding and absence of the FtsZ gene. Furthermore, they exhibit large genomes up to $12.5 \mathrm{Mb}$, and possess a high number of secondary metabolites as assessed by in silico genomic analysis. These characteristics have also revealed the presence of potential anticancer activity. Based on these promising characteristics, we wanted to investigate Planctomycetes as a source for natural products with anticancer properties. Organic and aqueous extracts were obtained from cultivated Planctomycetes strains originated from a variety of habitats such as marine systems (free living or attached to marine algae), deep marine iron hydroxide deposits, brackish water and glacier ice system. The extracts were screened for ability to inhibit cell growth, or induce cell death on two cancer cell lines, the human prostatic cancer cell line PC3, and human acute myeloid leukaemia (AML) cell line MOLM-13, as well as normal rat kidney epithelial cell line (NRK). Out of 39 strains, five exhibited cytotoxicity toward NRK cells, whereas 32 of the strains were toxic to the AML cell line, and four were toxic to the PC3 cell line. Two strains showed high toxicity and selectivity toward both the cancer cell lines over the NRK-cells, and are potential producers of anti-cancer compounds. We found no correlation between bioactivity and strains habitat and geographic location but regarding phylogeny some Rhodopirellula spp. showed higher toxicity toward MOLM-13 cells. These results from the first anticancer screening with Planctomycetes showed that these peculiar microorganisms should be further explored for anti-cancer compounds, and that more effort must be put in providing culture collections for drug development purposes.

Keywords: planctomycetes, anticancer, MOLM-13, PC3, NRK 


\section{INTRODUCTION}

Biotechnological search for new natural products is of utmost importance for the well-being and sustainability of humanity in the fight against many deadly diseases such as cancer and bacterial infections due to development of drug resistance (O'Neill, 2016). In Europe, cancer represents the second most important cause of death and morbidity with more than 3.7 million new cases and 1.9 million deaths each year (World Health Organization, 2012). In the United States, values of 1.7 million new cancer cases diagnosed and 0.6 million cancer deaths were estimated for 2017 (Siegel et al., 2017). As the prophylactic treatment to prevent cardiovascular diseases improves, it is expected that cancer will become the leading cause of death within few years (Heron and Anderson, 2016). This increase in cancer incidents represents new challenges. As the population ages, there will be a need for novel therapeutics with less harmful side-effects like cardiac failure or bone marrow depletion, often associated with therapy-induced mortality in elderly patients.

In the development of new therapeutics, the majority of drug candidates are natural derived compounds (Imhoff et al., 2011). Some phyla of bacteria, Actinobacteria, Myxobacteria and Cyanobacteria, are well known producers of secondary metabolites (Jeske et al., 2016) and have been extensively studied for bioactive compounds. Traditionally, terrestrial organisms have been targeted for the search of novel antibacterial compounds and secondary metabolites. Therefore, special attention is directed toward marine biological sources (Joseph and Sujatha, 2010) and less explored bacterial phyla. The marine environment is a huge ecosystem still highly underexplored. It thus represents a vast source for novel bioactive molecules that can fulfill the ever-increasing need for new therapeutics to meet the increasing demand of pharmaceuticals. The oceans are inhabited by an immense diversity of microorganisms that only recently started to be unveiled. Estimations foresee numbers exceeding $10^{29}$ bacterial cells in the open ocean, with an average cell concentration of $10^{6}$ per milliliter of seawater (Whitman et al., 1998; Amaral-Zettler et al., 2010). It has become notorious that the study of novel bacterial phyla could lead to new bioactive molecules (Bredholt et al., 2008). One of these phylogenetic groups are the Planctomycetes, bacteria that have an intricate, still not fully understood, cell biology with complex life cycles and large genomes. Recently, Planctomycetes have proven the capacity to produce antibiotics and antifungal molecules and also genome mining has demonstrated their promising biotechnological potential (Donadio et al., 2007; Jeske et al., 2013; Graça et al., 2016; Jeske et al., 2016; Boedeker et al., 2017). This is due to the presence of secondary metabolite genes or clusters related to various pathways for the production of several bioactive molecules, including some antitumor compounds like epothilone (Graça et al., 2016).

Besides the in silico study of its potential, no study has hitherto addressed the anti-cancer proprieties of Planctomycetes. In fact, the study presented here is the first anticancer screening performed with Planctomycetes assessing the induction of apoptosis and the decrease of growth in cancer cell lines. Acute myeloid leukemia (AML) cell lines were chosen because
AML is one of the most aggressive forms of leukemia and is associated with high rate of chemotherapy resistant relapse, and dose-limiting side-effects. Moreover, therapies developed toward leukemia have high translational value to other cancers. We also tested for activity toward a solid tumor derived cell line, using prostate cancer (PC) cell lines since PC is one of the most common cancer types and with high mortality rates, especially in western countries. PC is the leading cause of death from cancer in United States (Siegel et al., 2017) and the third most common cause of death in Europe (Bray and Kiemeney, 2017). The results obtained with both cancer cell lines (AML and PC) were compared with the ability to induce cell death in a normal epithelial cell line (NRK). High toxicity was obtained against AML cells with both aqueous and organic extracts from several strains whereas a reduced number of organic extracts were effective against PC cells. Two organic extracts exhibited high toxicity toward both cancer cell lines and not toward control NRK cells which makes them two good candidates for the production of anticancer compounds. Our results show that Planctomycetes represent a promising source for novel molecules that can become anticancer drug leads.

\section{MATERIALS AND METHODS}

\section{Bacterial Collections}

The Planctomycetes strains used in this study were obtained from several different habitats (Table 1), namely marine iron hydroxide deposits (13 strains), marine water column (1 strain), macroalgal surface (18 strains), a meromictic lake (5 strains) and a glacier ice inside a cave (2 strains). The strains affiliate to diverse phylogenetic clusters within the Planctomycetes phylum (Supplementary Figure S1). The Planctomycetes bacterium strain Pir4_P6_1 and Planctomycetes bacterium strain Pir4_P6_2 will be here designated as P6_1 and P6_2. The phylogeny of these two strains is allocated to Pir4 based on the Silva database (Yilmaz et al., 2014). The type strains of Rhodopirellula baltica, strain $\mathrm{SH}_{1}{ }^{T}$ was isolated from the Kiel Fjord in the Baltic Sea (no GPS coordinates available). All the Planctomycetes isolated from Portugal (from the surface of macroalgae in three locations in the northern coast) were previously described (Lage and Bondoso, 2011). Strains CcC6, CcC8, FC9.2, FC18, UC8, UC9, UC13, UC16, UC21, and UC49.1 were collected from Carreço, Portugal $\left(41^{\circ} 44^{\prime} \mathrm{N}, 8^{\circ} 52^{\prime} \mathrm{W}\right)$, strains FF4, UF3, UF4.2, UF6 and Sm 4 were collected in Porto, Portugal $\left(41^{\circ} 09^{\prime} \mathrm{N}\right.$, $\left.8^{\circ} 40^{\prime} \mathrm{W}\right)$ and strain Gr7 from Aveiro $-40^{\circ} 38^{\prime} \mathrm{N}, 8^{\circ} 52^{\prime} \mathrm{W}$. The strains isolated from marine iron hydroxide deposits (MgM4h, TBK2h, VLsL2h, VLoJ2h, VLoJ4h, K2D, VLrD4, VLbF2, Plm2, TBK1, VLsL4r, VLsK4lr, VLpG4r) were obtained from the South Pacific Ocean $\left(176^{\circ} 36^{\prime} \mathrm{W}, 22^{\circ} 10.82^{\prime} \mathrm{S}\right.$ VaiLili). Detailed descriptions of locations, strains and isolation procedures are given in Storesund et al. (2018). The five strains (9mWe, $7 \mathrm{mR}, 1 \mathrm{~mW}, 8 \mathrm{~mW}, 15 \mathrm{~mW})$ collected from the meromictic lake Sælenvannet south of Bergen, Norway $\left(60^{\circ} 19 \mathrm{~N}, 05^{\circ} 16 \mathrm{E}\right)$, was collected in 2012 using the same sampling protocol as 
described in Ovreås et al. (1997), covering both aerobic surface layer $(1 \mathrm{~m})$ as well as the anaerobic water masses below the chemocline $(7,8,9$, and $15 \mathrm{~m})$. Two of the strains (L1 and L2) were isolated from the surface of the macroalgae Saccharina nigripes collected from Hansneset in Kongsfjorden on Svalbard $\left(78^{\circ} 59 \mathrm{~N}, 11^{\circ} 57 \mathrm{E}\right)$, using the protocol described previously by Bengtsson and Øvreås (2010). Two strains (P6_1 and P6_2) were isolated from a glacier ice situated inside the cave Svarthammarhola in northern Norway $\left(67^{\circ} 13^{\prime} \mathrm{N}, 15^{\circ} 31^{\prime} \mathrm{E}\right.$ at $295 \mathrm{~m}$ a.s.l.). The cave system is described in detail by Lauritzen et al. (2018), ice masses was collected and brought frozen to the laboratory for further processing as described in Sæbø (2018).

\section{Identification of Planctomycetes Strains}

All strains were identified based on the analysis of the $16 \mathrm{~S}$ rRNA gene. The identification of the strains isolated from Portugal has previously been described (Lage and Bondoso, 2011). For the other strains, full length 16S rRNA gene sequences were obtained from isolated strains as described in Storesund and Øvreås (2013). Pure colonies were picked from plates and transferred to $50 \mu \mathrm{L}$ sterile water. These cell slurries were subjected to three cycles of freeze-thawing to lyse the cells, and these mixtures were then used as template in the PCR reaction. The $16 \mathrm{~S}$ rRNA gene was amplified using the primer combination A8f with 1542r, targeting bacterial $16 \mathrm{~S}$ rRNA genes. The PCR products were purified using

TABLE 1 | Phylogeny, habitat and location of Planctomycetes strains used in this study.

\begin{tabular}{|c|c|c|c|c|}
\hline Strain & Phylogeny & Habitat & Location & Country \\
\hline MgM4h & Blastopirellula cremea & Iron hydroxide deposits & South Pacific & Fidji/Tonga \\
\hline $9 \mathrm{mWe}$ & Blastopirellula cremea & Meromictic lake & Fana & Norway \\
\hline TBK2h & Blastopirellula marina & Iron hydroxide deposits & South Pacific & Fidji/Tonga \\
\hline VLsL2h & Blastopirellula sp. & Iron hydroxide deposits & South Pacific & Fidji/Tonga \\
\hline VLoJ2h & Blastopirellula sp. & Iron hydroxide deposits & South Pacific & Fidji/Tonga \\
\hline VLoJ4h & Blastopirellula sp. & Iron hydroxide deposits & South Pacific & Fidji/Tonga \\
\hline FC18 & Mariniblastus fucicola & Fucus spiralis & Carreço & Portugal \\
\hline $\mathrm{K} 2 \mathrm{D}$ & Planctomycetes bacterium Pir 4. & Iron hydroxide deposits & South Pacific & Fidji/Tonga \\
\hline P6_1 & Pir 4 (lce cluster) & Cave Ice & Svarthamarhola & Norway \\
\hline P6_2 & Pir 4 (Ice cluster) & Cave Ice & Svarthamarhola & Norway \\
\hline VLrD4 & Gimesia maris & Iron hydroxide deposits & South Pacific & Fidji/Tonga \\
\hline VLbF2 & Gimesia maris & Iron hydroxide deposits & South Pacific & Fidji/Tonga \\
\hline Plm2 & Gimesia maris & Iron hydroxide deposits & South Pacific & Fidji/Tonga \\
\hline UC49.1 & Rhodopirellula baltica & Ulva sp. & Carreço & Portugal \\
\hline $\mathrm{SH} 1$ & Rhodopirellula baltica & Water column & Baltic Sea & Germany \\
\hline UC21 & Rhodopirellula baltica & Ulva sp. & Carreço & Portugal \\
\hline L1 & Rhodopirellula islandica & Saccharina nigripes & Kongsfjorden & Norway \\
\hline $\mathrm{CcC6}$ & Rhodopirellula lusitana & Chondrus crispus & Carreço & Portugal \\
\hline $\mathrm{CcC8}$ & Rhodopirellula lusitana & Chondrus crispus & Carreço & Portugal \\
\hline Sm4 & Rhodopirellula lusitana & Sargassum moticum & Porto & Portugal \\
\hline UC13 & Rhodopirellula lusitana & Ulva sp. & Carreço & Portugal \\
\hline UC16 & Rhodopirellula lusitana & Ulva sp. & Carreço & Portugal \\
\hline UF6 & Rhodopirellula lusitana & Ulva sp. & Porto & Portugal \\
\hline L2 & Rhodopirellula lusitana & Saccharina nigripes & Kongsfjorden & Norway \\
\hline UC9 & Rhodopirellula rubra & Ulva sp. & Carreço & Portugal \\
\hline $7 \mathrm{mR}$ & Rhodopirellula sp. & Meromictic lake & Fana & Norway \\
\hline FC9.2 & Rhodopirellula sp. & Fucus spiralis & Carreço & Portugal \\
\hline FF4 & Rhodopirellula sp. & Fucus spiralis & Porto & Portugal \\
\hline TBK1 & Rhodopirellula sp. & Iron hydroxide deposits & South Pacific & Norway \\
\hline VLsL4r & Rhodopirellula sp. & Iron hydroxide deposits & South Pacific & Fiji/Tonga \\
\hline VLsK4Ir & Rhodopirellula sp. & Iron hydroxide deposits & South Pacific & Fidji/Tonga \\
\hline VLpG4r & Rhodopirellula sp. & Iron hydroxide deposits & South Pacific & Fidji/Tonga \\
\hline UC8 & Roseimaritima ulvae & Ulva sp. & Carreço & Portugal \\
\hline UF3 & Roseimaritima ulvae & Ulva sp. & Porto & Portugal \\
\hline UF4.2 & Roseimaritima ulvae & Ulva sp. & Porto & Portugal \\
\hline Gr7 & Rubinisphaera brasiliensis & Gracilaria bursa-pastoris & Aveiro & Portugal \\
\hline $1 \mathrm{~mW}$ & Rubinisphaera sp. & Meromictic lake & Fana & Norway \\
\hline $8 \mathrm{~mW}$ & Rubinisphaera sp. & Meromictic lake & Fana & Norway \\
\hline $15 \mathrm{~mW}$ & Rubinisphaera sp. & Meromictic lake & Fana & Norway \\
\hline
\end{tabular}


ExoStar as described by manufacturer (USB Corporation), and subsequently sequenced using Big-Dye.3.1 kit (ABI 3700 PE; Applied Biosystems). Sequencing was done on an ABI3700 sequencing system (Applied Biosystems) at Bergen Sequencing facility $^{1}$.

All 16S rRNA gene sequences of the various strains were deposited in NCBI database under the following accession numbers: EF589350.2 (UC16), EF589352.2 (CcC6), HQ845424.1 (CcC8), HQ845450.1 (FC18), HQ845477.1 (Gr7), HQ845503.1 (Sm4), HQ845508.1 (UC8), HQ845509.1 (UC9), HQ845513.1 (UC13), HQ845517.1 (UC21), HQ845532.1 (UF3), HQ845534.1 (UF4.2), HQ845536.1 (UF6), KX495344.1 (FC9.2), KX495345.1 (UC49.1), JN236500.1 (FF4), MH686033 (P6.1), MH686034 (P6.2), MH916628 (9mWe), MH916629 (1mW), MH916630 (8mW), MH916631 (15mW), MH916632 (7mR), MH916640 (L1), MH916641 (L2), MH918141 (MgM4h), MH918142 (TBK2h), MH918143 (VLsL2h), MH918144 (VLoJ2h), MH918145 (VLoJ4h), MH918146 (K2D), MH918147 (VLrD4), MH918148 (Plm2), MH918149 (VLbF2), MH918150 (TBK1), MH918151 (VLsL4r), MH918152 (VLsK4lr), MH918153 (VLpG4r), NC_005027.1 (SH1).

\section{Phylogenetic Analysis of Bacteria}

The 16S rRNA gene sequences of the bacteria were alignment using MEGA 6 (Molecular Evolutionary Genetics Analysis) software, that permits to infer overtime the molecular evolutionary between genes, genomes and species (Tamura et al., 2013). The construction of the phylogenetic tree was performed the using calculation method maximum likelihood ML in MEGA 6, applying General Time Reversible model and Gamma distributed with Invariant sites $(\mathrm{G}+\mathrm{I})$. As outgroup, Candidatus Scalindua brodae clone EN8 was used.

\section{Cultivation of Planctomycetes}

Pure cultures of Planctomycetes were cultivated in $250 \mathrm{~mL}$ M13 or M30 media with $70-90 \%$ seawater with the exception of the ice derived isolates that were cultivated in M30 with $18 \%$ seawater (Table 1 ) at $25^{\circ} \mathrm{C}$, and $120 \mathrm{rpm}$ After 7 days incubation, the cultures were centrifuged for $15 \mathrm{~min}$ at $10,000 \times g$, and the supernatant discarded. The cell pellets were washed twice with sterile water and freeze-died for approximately $18 \mathrm{~h}$ (with temperature below $-40^{\circ} \mathrm{C}$ and about $4 \times 10^{-2}$ atm pressure). The final biomass was weighted and kept at $-20^{\circ} \mathrm{C}$ until further processing.

\section{Preparation of Planctomycetes Extracts for Cell Lines Experiments}

Six mL of methanol: MilliQ water: chloroform (1:1:1) were added to each freeze-dried pellet. Six $\mathrm{mL}$ of the mixture without cells were used as an extraction control. The samples were homogenized (Tempest Virtishear I.Q. from Virtis, Gardiner NY fitted with $10 \mathrm{~mm}$ rotor), at $20000 \mathrm{rpm}$, for two periods of $30 \mathrm{~s}$, with cooling on ice for $10 \mathrm{~s}$ between the cycles. The samples were allowed to extract for $1 \mathrm{~h}$ at $4^{\circ} \mathrm{C}$, with agitation after $30 \mathrm{~min}$,

${ }^{1}$ www.seqlab.uib.no and then centrifuged at $450 \times g$ for $30 \mathrm{~min}$ at $4^{\circ} \mathrm{C}$, to separate the aqueous and organic phases. For each sample: (i) the organic phase (bottom phase) was carefully transferred to a separate tube and evaporated to dryness in a vacuumed centrifuge (Eppendorf concentrator plus, Eppendorf AG, Hamburg, Germany). The dried extract was dissolved in DMSO in a ratio of $10 \mathrm{mg}$ of initial freeze-dried biomass of the bacterial culture to $25 \mu \mathrm{L}$ of DMSO. (ii) The aqueous phase (top phase) was treated in a similar way as the organic extract with the exception of the final step. The aqueous extracts were added $75 \mu \mathrm{L}$ of MilliQ water, in addition to $25 \mu \mathrm{L}$ DMSO for each $10 \mathrm{mg}$ initial freeze-dried biomass.

\section{Cancer Cell Lines and Cytotoxicity Assays}

Planctomycetes extracts were tested for their capacity to induce cell death in the normal epithelial rat kidney cell line NRK (ATCC no: CRL-6509), the human AML cell line MOLM-13 (Matsuo et al., 1997; Quentmeier et al., 2003) and in the human PC cell line PC3 (ATCC no.: CRL-1435).

MOLM-13 cells were cultured in RPMI medium (Sigma R5886), supplemented with $10 \% \quad(\mathrm{v} / \mathrm{v})$ fetal calf serum (Sigma F7524), $0.2 \mathrm{mM}$ L-glutamine and added $50 \mathrm{IU} / \mathrm{mL}$ penicillin and $0.1 \mathrm{mg} / \mathrm{mL}$ streptomycin. The cells were cultured to a density between 8 and $80 \times 10^{4}$ cells $/ \mathrm{mL}$, and diluted by adding fresh medium with supplements. NRK and PC3 cells were cultured in Dulbecco's modified Eagle's medium (DMEM - Sigma D-6429), with the same supplements as for MOLM-13 cells. The PC3 and NRK cells are adherent, and at $90 \%$ confluence, the cells were detached by mild trypsin treatment $(0.30 \mathrm{mg} / \mathrm{mL}$ trypsin for $5 \mathrm{~min}$ at $37^{\circ} \mathrm{C}$ ) and reseeded in fresh medium with supplements at $40-50 \%$ confluence. Cells were incubated at $37^{\circ} \mathrm{C}$, in a humidified atmosphere with $5 \% \mathrm{CO}_{2}$. All media, serum and supplements, and reagents were from Sigma-Aldrich, St. Louis, MO, United States.

The cytotoxicity experiments were performed in 96-well plates. One hundred $\mu \mathrm{L}$ containing 6000 cells of NRK or PC3 cell lines were placed in each well $24 \mathrm{~h}$ before the addition of the extracts to allow cells attachment to the substratum. After $24 \mathrm{~h}$ the medium was replaced by fresh medium and the extracts were added. MOLM-13 cell suspensions (20,000 cells/well in $100 \mu \mathrm{L})$ were added to the plates at the same time as the extracts. For all cell lines, $1 \mu \mathrm{L}$ of the organic extracts or $4 \mu \mathrm{L}$ of the aqueous extracts were added, respectively, to 99 or $96 \mu \mathrm{L}$ of cell culture. The same volume of DMSO was used as solvent control and a negative control of $100 \mu \mathrm{L}$ cell culture was also made. Cells were incubated with the extracts for $72 \mathrm{~h}$. The viability of the cells was first monitored using the WST-1 assay metabolic assay (Roche, Mannheim, Germany) following the manufacturers instruction. Thereafter, the cells were fixed with $2 \%$ buffered formaldehyde ( $\mathrm{pH} 7.4$ ) containing $0.01 \mathrm{mg} / \mathrm{mL}$ of the DNA-specific fluorescent dye, Hoechst 33342 and morphology of the nuclei was visualized by fluorescence microscopy (Nikon Diaphot 300 fitted with a $40 \times$ Flu-Phase contrast lens and a DS-Fi3 camera) as described 


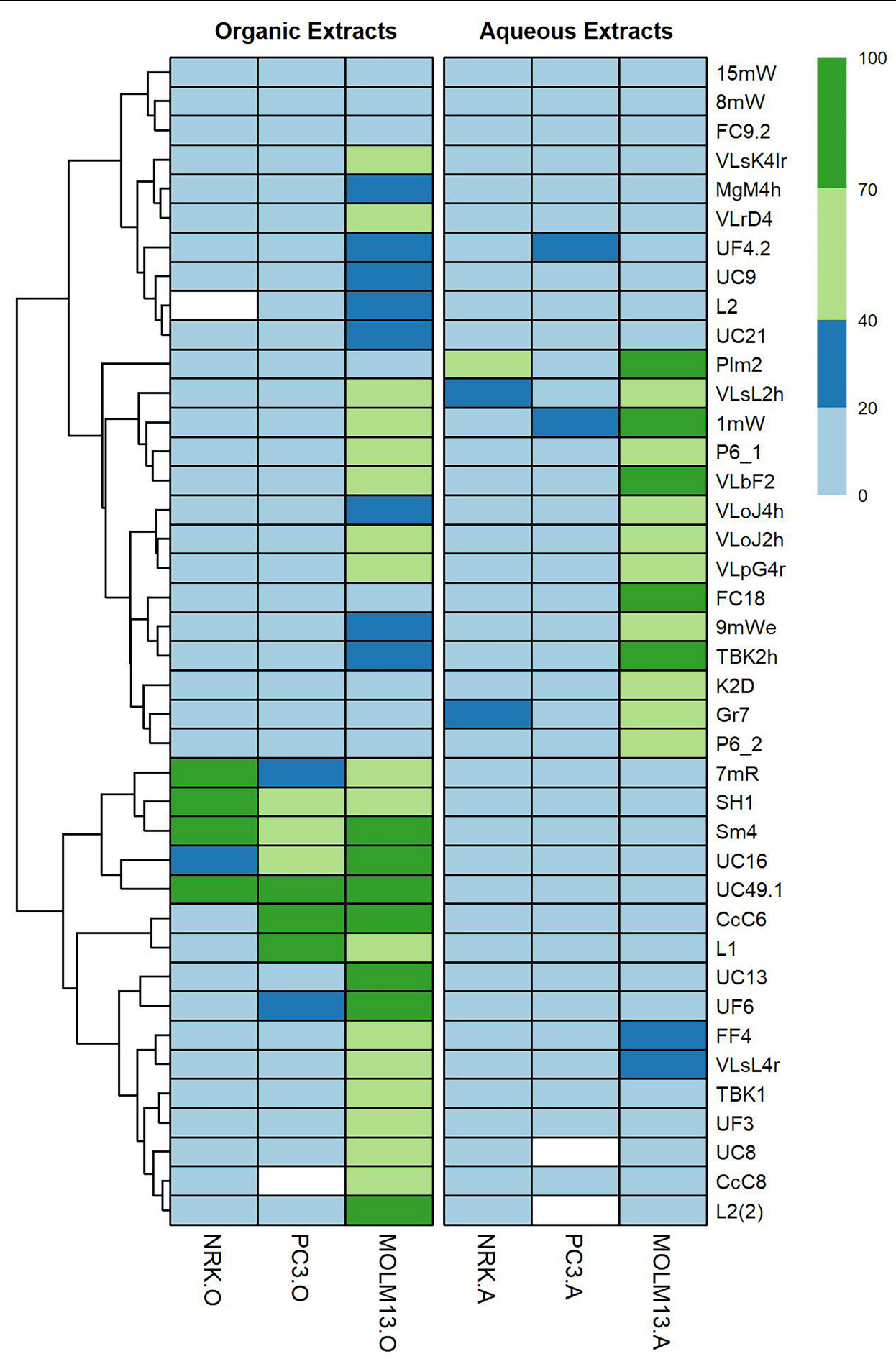

FIGURE 1 | Heat-map showing the different degrees of toxicity that organic and aqueous extracts of Planctomycetes induced in NRK, MOLM-13 and PC3 cell lines. From strain L2, extracts were obtained after 7 and 15 days of cultivation [L2 and L2(2), respectively]. Heat-map scale: 0-20\% - no toxicity; 20-40\% - low toxicity; 40-70\% - intermediate toxicity; 70-100\% - high toxicity. White boxes - Not evaluated. Graph was created in R studio program, using pheatmap package. Cluster analysis was based on Euclidean Distance.

by Prestegard et al. (2009). A minimum of hundred cells from each cell line were used to determine cell death microscopically. All extracts were tested for cytotoxic activity 3-5 times for each concentration. The combination of WST-1 assay and microscopic evaluation has previously been shown to give reliable results (Vu et al., 2016; Viktorsson et al., 2017) and also complement 
each other. WST-1 can detect growth inhibitory activity, and the nuclear evaluation is particularly useful if working with colored extracts.

\section{Statistical Analysis}

Statistical analyses and visualization was done in R (R Core Team, 2017) using the vegan (Oksanen et al., 2015), ggplot2 (Wickham, 2009) and pheatmap packages (Kolde, 2015).

To see if the toxic effect of Planctomycetes on the different cancer cell lines was related to strain phylogeny (Blastopirellula, Gimesia, Mariniblastus, Rhodopirellula sp., Rhodopirellula lusitana, Roseimaritima, Rubinisphaera or Pir 4) or original habitat (ice, iron hydroxides, meromictic lake, macroalgal surface or seawater) we used analysis of similarities (ANOSIM, vegan). The response variable was a dissimilarity matrix of individual strain effects (aqueous and organic, $n=6$ ) on the three cancer cell lines, and the predictors were strain phylogenetic affiliation and original habitat. A PCA analysis (999 perm) was used to further examine correlations between strain toxicity and the different cell lines.

\section{RESULTS}

A total of 39 Planctomycetes were screened for cytotoxic bioactivity toward human AML cell line (MOLM-13) and human prostatic cancer cell line (PC3). The normal rat kidney epithelial cell line (NRK) was used to be able to distinguish between general cytotoxic activity (all three cell lines affected), and anti-cancer activity (cancer cell lines affected, but not NRK cell lines). All cells were analyzed for metabolic activity using the WST-1 assay which measures enzymatic conversion of a tetrazolium salt into a colored metabolite. However, as several of the Planctomycetes possess coloration that interferes with the WST-1 colorimetric assay, cytotoxicity was therefore only assessed through the nuclear morphology (see Supplementary Figure S2).

All the Planctomycetes were cultivated for 7 days except strain L2, which was also grown for 15 days to assess a longer stationary phase on the potential production of bioactive molecules.

The extracts were tested at $1 \%$ for the organic extracts and $4 \%$ for the aqueous extracts, both corresponding to extracts from $0.4 \mathrm{mg}$ freeze-dried material per $0.1 \mathrm{~mL}$ cell culture medium. First, it was tested whether the extracts exhibited cytotoxicity during 24-h incubation. However, we noticed only modest cytotoxicity for all extracts after this incubation time. Since many cytostatics, like metabolic inhibitors, have a protracted cytotoxic effect, we decide to incubate the cells with the Planctomycetes extracts for $72 \mathrm{~h}$ before assessing for cell death. We divided the cytotoxic potential of the extracts into high - $\mathrm{H}(>70 \%$ cell death), intermediate - I (40-70\% cell death), low - L (20-40\% cell death) or no ( $<20 \%$ cell death) (Supplementary Table S1). In total, 40 aqueous and 40 organic extracts were analyzed. The different cell lines were screened under the microscope for apoptotic nuclei and their percentage calculated (Supplementary Figure S2). Based on these values, a heatmap of the cytotoxic effects was constructed (Figure 1). The

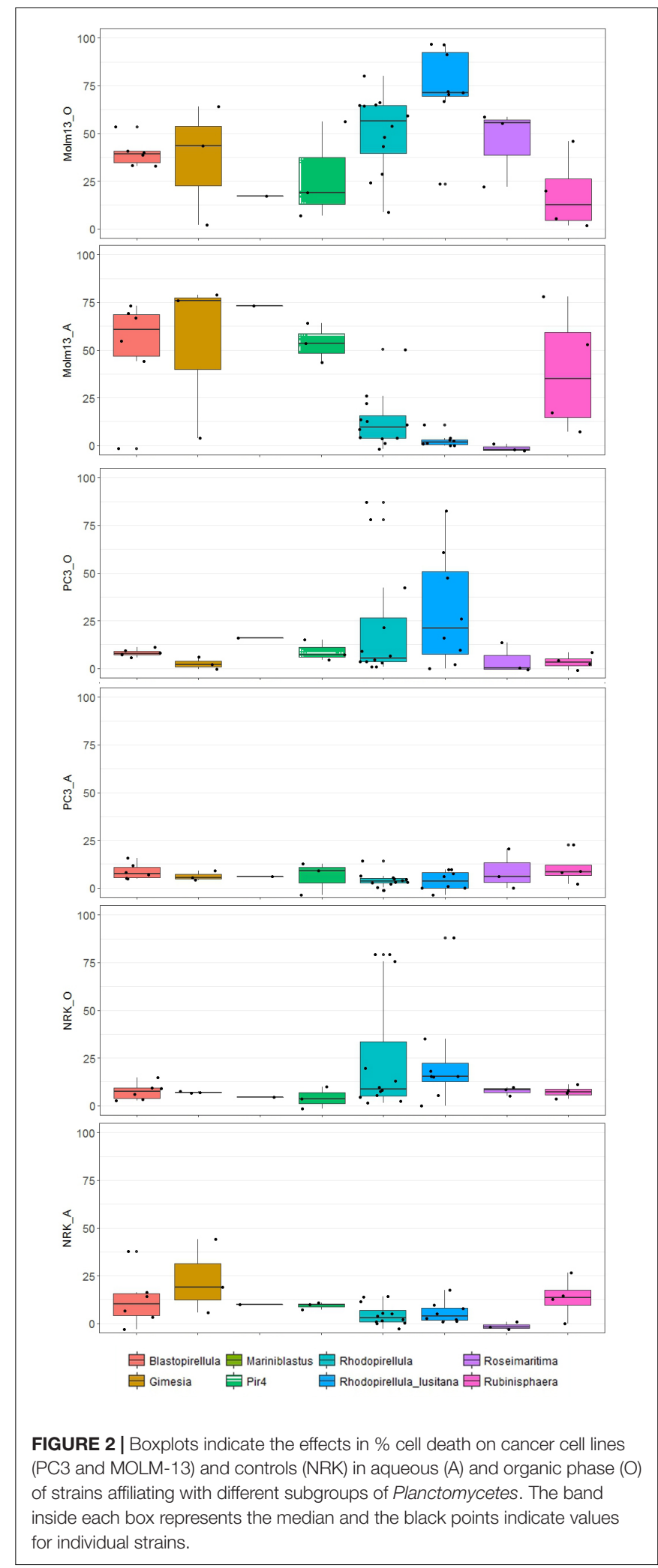

organic extracts showed higher cytotoxic capacity than the aqueous extracts both in number (55\% of the organic and 35\% of the aqueous) and intensity (mean and median cell death 
was, respectively, 26.4 and $12.1 \%$ for the organic and 13.6 and $6.0 \%$ for the aqueous extracts) (Figure 1 and Supplementary Table S1).

Only five extracts showed intermediate or high activity toward NRK cells; the aqueous extract from strain Plm2, and the organic extracts from strains 7mR, SH1, UC49.1 and Sm4. High or intermediate activity toward PC3 prostate cancer cells was detected only in the organic extracts from strains CcC6, L1, SH1, Sm4, UC16, and UC49.1. Of these, strains SH1, Sm4 and UC49.1 were also cytotoxic toward NRK cells, but strains CcC6 and L1 appeared selective toward PC3 cells over NRK cells.

In general the MOLM-13 cells were much more sensitive toward the planctomycetal extracts than the other two cell lines. When counting strains causing high and intermediate cytotoxicity, $18 \%$ of the strains were $\mathrm{H}$, and $43 \% \mathrm{I}$ in the organic extracts, and $13 \%$ were $\mathrm{H}$, and $25 \% \mathrm{I}$ in the aqueous extracts. Only strains P6.1, VLbF2, 1mW, VLsL2h, VLoJ2h, and VLpG4r produced cytotoxic activity in both extracts, the remaining strains had cytotoxicity in only one of the extracts.

From strain L2, extracts were obtained after 7 and 15 days of cultivation. After 7 days the organic extract was bioactive against MOLM-13 with low cytotoxicity (24\%) but after the 15 days a threefold increase in cytotoxicity (70\%) was seen (Figure 1 and Supplementary Table S1).

Some strains stood out as particularly promising regarding anticancer activity. The organic extracts from the Rhodopirellula lusitana strains CcC6 ( $\mathrm{H}-83 \%$ PC3 and I - 72\% MOLM-13) and Rhodopirellula sp. L1 ( $\mathrm{H}-87 \%$ PC3 and I - 59\% MOLM13) induced cell death in the cancer cell lines selectively, i.e., strong activity toward both cancer cell lines, but not NRKcells (Figure 1 and Supplementary Table S1). Another striking feature was that several Planctomycetes were selective toward MOLM-13 cells only, such as Rhodopirellula lusitana strain CcC8 (I - 67\%), UC13 ( $\mathrm{H}-91 \%)$ and Gimesia maris VLrD4 (I $44 \%)$ only in the organic phase. Furthermore, Rhodopirellula sp. VLpG4r (I (aq) - 50 \% and I (org) - 43 \%), Pir4_P6_1 (I (aq) $-64 \%$ and I (org) - $56 \%$ ), Rubinisphaera sp. 1MW (H (aq) $-78 \%$ and I (org) - $46 \%)$, Gimesia maris VLbF2 $(\mathrm{H}$ (aq) $-76 \%$ and I (org) - $64 \%$ ), Blastopirellula sp. VLsL2h (I (aq) $-69 \%$ and I (org) - 53\%) and Blastopirellula sp. VLoJ2h (I (aq) - $44 \%$ and I (org) - 41\%) showed activity both in aqueous and organic phases. $R$. lusitana seems to be highly bioactive in the organic extracts but not in the aqueous extracts (Figure 2). The most cytotoxic strains belong to Rhodopirellula spp. (Figure 2).

In this study, a broad range of phylogenetic different Planctomycetes was selected covering diverse habitats and geographical origins (Table 1 and Supplementary Figure S1). Effects of individual strains on cancer cell lines differed between different phylogenetic groups (ANOSIM, $p<0.005$ ), with Rhodopirellula sp. and R. lusitana, in particular, showing higher toxicity toward MOLM-13 cells. However, no distinct patterns regarding habitat or geographical location (data not shown) were identified. In line with the ANOSIM analysis, PCA analysis also showed that the organic extracts from Rhodopirellula sp. and $R$. lusitana as well as Rubrinisphaera strains had stronger effects on MOLM-13 cells than aqueous extracts (Figure 3). However, the opposite was the case for the extracts from Blastopirellula, Gimesia, Pir 4 and Rubinisphaera strains (Figure 3).

\section{DISCUSSION}

In this study, we have demonstrated the capacity of Planctomycetes to induce apoptosis and decrease cell growth in human and rat cell lines. A considerable number of Planctomycetes strains contained bioactivity which was active toward one or both cancer cell lines (MOLM-13 AML cells and PC3 prostate cancer, but not to the normal NRK kidney epithelial cells. Moreover, a higher number of Planctomycetes were able to affect the MOLM-13 cells (32 strains) compared to the PC3 cells (six strains). We have thus showed that Planctomycetes exhibit anti-cancer activity that could become useful in future drug development.

Little is known about bioactive substances in Planctomycetes, as compared to other microorganisms such as Actinobacteria, Myxobacteria, and Cyanobacteria. However, Planctomycetes have recently been recognized as important producers of bioactive compounds by both in silico genome mining analyses and molecular screening approaches. These analyses revealed the presence of genes related to various pathways for the production of several bioactive molecules, including some antitumor compounds like epothilone (Donadio et al., 2007; Graça et al., 2013; Wang et al., 2014; Graça et al., 2016; Ivanova et al., 2017; Vollmers et al., 2017). It is therefore very promising that several of our Planctomycetes strains isolated from various ecosystems showed significant cytotoxic activity toward the MOLM-13 cells and the human prostatic PC3 cells.

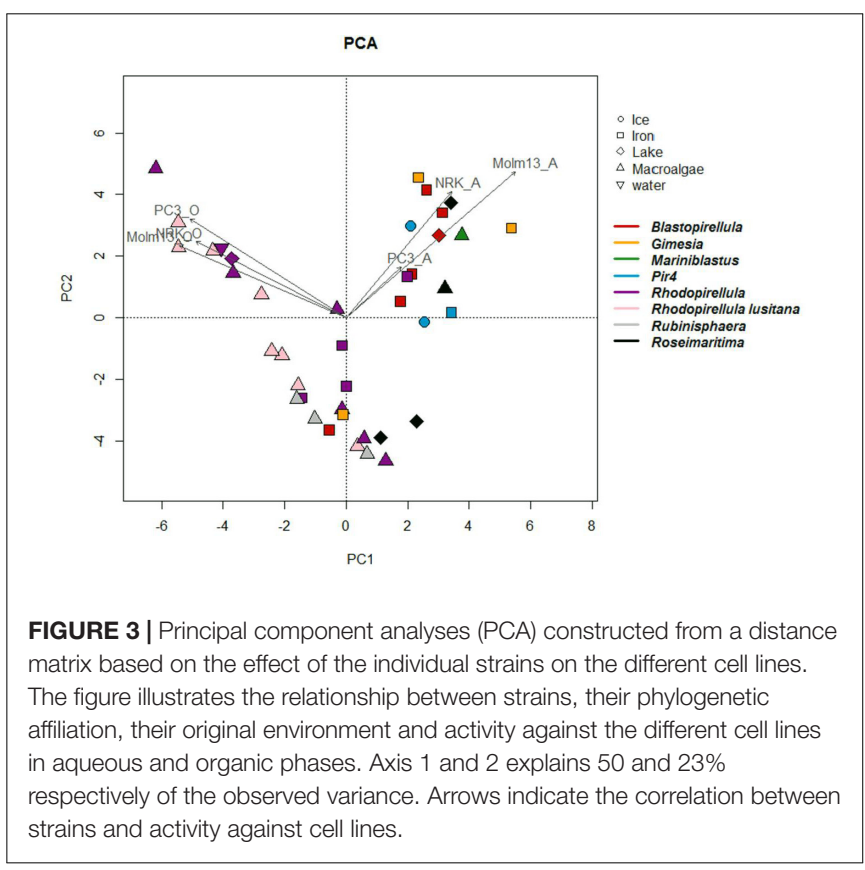


The cultivation of Planctomycetes is challenging as they are slow growing bacteria and therefore production of intermediate and high scale of biomass is not always straightforward. In this study we were able to establish growth conditions that allowed considerable biomass production. For strain L2 a prolonged growth period (15 days instead of 7 days) was included and results from this experiment seemed to favor the formation of bioactive molecules (Figure 1). It should be emphasized that in both situations the cultures were in the same stationary growth phase. The only differences are the duration for the production of bioactive molecules or an increased stress by the aging of the culture. Planctomycetal growth time is therefore an important parameter to be considered in future work.

Four strains induced high toxicity $(>70 \%)$ against NRK control cells. Interestingly, strain UC49.1 was highly toxic toward all cell lines in the organic extract, but produced no toxic substances in the aqueous extracts toward any of the cell lines. This demonstrates that the two obtained extracts, aqueous and organic, were different regarding the composition on Planctomycetes metabolites, similar to what has been demonstrated for cyanobacteria (Liu et al., 2014; Humisto et al., 2015). Still six strains showed activity in both extracts (>40\%), which is likely to be caused by compounds with intermediate hydrophobicity present in both extracts.

The MOLM-13 cells were in general more sensitive toward the extracts compared to the PC cells (Figure 1). We have previously observed that the activity toward the MOLM-13 cells in the aqueous extracts can be due to high levels of adenosine (Prestegard et al., 2009; Liu et al., 2014). Adenosine has been shown to induce apoptosis in MOLM-13 cells (Tanaka et al., 1994). However, in our study, we used non-heat inactivated fetal bovine serum, where adenosine deaminase is intact, and able to convert adenosine into the inactive metabolite inosine. Thus, the anti-AML activity seen in the aqueous extracts in our experimental assays could not be due to adenosine. The selectivity toward AML compared to NRK or PC3 could be due to the more rapid proliferation rate of MOLM-13 cells, and could point toward a mode of action related to DNA replication or the mitotic machinery.

The most promising results regarding the anticancer activity were obtained with the organic extracts from the $R$. lusitana strains (CcC6 and L1, Figure 1). They showed activities toward both MOLM-13 cells and PC3 cells, but not toward the NRK cells. Interestingly the phylogenetic related $R$. baltica also produced extracts showing high toxicity toward the cancer cell lines but also against the NRK cells. This demonstrates the importance of a broad culture collection for bioprospecting purposes, since even highly related strains can give very different bioactivities.

We did not find a strong correlation between biogeography or habitat of the most promising candidates, as L1 was isolated from a kelp surface from Kongsfjorden in the Arctic (Svalbard, Norway), whereas the CcC6 was isolated from the surface of Chondrus crispus of the Coast of Portugal. The cytotoxicity-producing Planctomycetes were ubiquitously distributed and adapted to tolerate fluctuations in salinity, temperatures, light and nutrient regimes.
This work further confirms the potential of Planctomycetes as producers of important bioactivities by extending them to the production of anti-cancer compounds. Planctomycetes attached to algal surfaces seemed to be most active toward the cell lines tested as they produced the most potent anti-cancer compounds in this study. This could be explained by the high level of competition in the complex environments of the macroalgal biofilms against other eukaryotic colonizers, which then might trigger Planctomycetes production of secondary metabolites. The production of chemicals toward their eukaryotic competitors may be fundamental to fight for their niche overcoming their slow growth rate. Therefore, these metabolites could selectively target cell signaling component exclusively found in eukaryotes. If these targets are evolutionary conserved, they might even be present in mammalian cells. Hitherto interspecies interactions of algae and bacteria and their resulting natural products are not well understood. As these bioactive molecules have the potential to be used for medical purposes, this study enlightens the importance of exploring molecules produced by Planctomycetes for drug development. In the light of the evolutionary history, large genome size and diverse metabolic pathways, we foresee that several unique and important compounds may appear in these enigmatic bacteria.

\section{AUTHOR CONTRIBUTIONS}

$\mathrm{RC}$ conducted the experiments, analyzed and interpreted the results, and wrote the manuscript. ES conducted the experiments, analyzed and interpreted the results. JS provider of strains, conducted the experiments, and analyzed and interpreted the results. L $\varnothing$ provider of strains, analyzed and interpreted the results, and wrote the manuscript. LH planned, analyzed, and interpreted the results, and wrote the manuscript. OL planned, provider of strains, analyzed and interpreted the results, and wrote the manuscript.

\section{FUNDING}

This research was partially supported by the Strategic Funding UID/Multi/04423/2013 through national funds provided by FCT - Foundation for Science and Technology and European Regional Development Fund (ERDF), in the framework of the program PT2020, the Structured Program of R\&D\&I INNOVMAR-Innovation and Sustainability in the Management and Exploitation of Marine Resources (reference NORTE-01-0145-FEDER-000035, Research Line NOVELMAR), funded by the Northern Regional Operational Program (NORTE2020) through the European Regional Development Fund (ERDF), the ERA-netLAC project "Cave ice microbiom: metabolic diversity and activity in response to climate dynamics and anthropogenic pollution CAVICE (DCC-0178)" funded by the Norwegian Research Council (Project No. 256162) and the EU H2020-TWINN-2015, BLUEandGREEN - Boosting scientific excellence and innovation capacity in biorefineries based on marine resources (Project No. 692419). This research was also supported by "The Norwegian Cancer Society". 


\section{SUPPLEMENTARY MATERIAL}

The Supplementary Material for this article can be found online at: https://www.frontiersin.org/articles/10.3389/fmars. 2018.00499/full\#supplementary-material

FIGURE S1 | Phylogenetic 16S rRNA gene tree generated by maximum-likelihood analysis based in General Time Reversible model and Gamma distributed with

\section{REFERENCES}

Amaral-Zettler, L., Artigas Luis, F., Baross, J., Bharathi, P. A. L., Boetius, A., Chandramohan, D., et al. (2010). "A global census of marine microbes," in Life in the World's Oceans: Diversity, Distribution, and Abundance, ed. A. D. McIntyre (Oxford: Wiley-Blackwell), 221-245. doi: 10.1002/9781444325508. ch12

Bengtsson, M. M., and Øvreås, L. (2010). Planctomycetes dominate biofilms on surfaces of the kelp Laminaria hyperborea. BMC Microbiol. 10:261. doi: 10.1186/ 1471-2180-10-261

Boedeker, C., Schüler, M., Reintjes, G., Jeske, O., Van Teeseling, M. C. F., Jogler, M., et al. (2017). Determining the bacterial cell biology of Planctomycetes. Nat. Commun. 8:14853. doi: 10.1038/ncomms 14853

Bray, F., and Kiemeney, L. A. (2017). "Epidemiology of prostate cancer in Europe: patterns, trends and determinants," in Management of Prostate Cancer: A Multidisciplinary Approach, eds M. Bolla and H. Van Poppel (Cham: Springer International Publishing), 1-27.

Bredholt, H., Fjærvik, E., Johnsen, G., and Zotchev, S. B. (2008). Actinomycetes from sediments in the trondheim fjord, norway: diversity and biological activity. Marine Drugs 6, 12-24. doi: 10.3390/md6010012

Donadio, S., Monciardini, P., and Sosio, M. (2007). Polyketide synthases and nonribosomal peptide synthetases: the emerging view from bacterial genomics. Nat. Prod. Rep. 24, 1073-1109. doi: 10.1039/b514050c

Graça, A. P., Bondoso, J., Gaspar, H., Xavier, J. R., Monteiro, M. C., De La Cruz, M., et al. (2013). Antimicrobial activity of heterotrophic bacterial communities from the marine sponge Erylus discophorus (Astrophorida, Geodiidae). PLoS One 8:e78992. doi:10.1371/journal.pone.007 8992

Graça, A. P., Calisto, R., and Lage, O. M. (2016). Planctomycetes as novel source of bioactive molecules. Front. Microbiol. 7:1241. doi: 10.3389/fmicb.2016.01241

Heron, M., and Anderson, R. N. (2016). Changes in the leading cause of death: recent patterns in heard disease and cancer mortality. NCHS Data Breif. 254, $1-8$.

Humisto, A., Herfindal, L., Jokela, J., Karkman, A., Bjørnstad, R., Roy Choudhury, R., et al. (2015). Cyanobacteria as a source for novel antileukemic compounds. Curr. Pharm. Biotechnol. 17, 78-91. doi: 10.2174/ 1389201016666150826121124

Imhoff, J. F., Labes, A., and Wiese, J. (2011). Bio-mining the microbial treasures of the ocean: new natural products. Biotechnol. Adv. 29, 468-482. doi: 10.1016/j. biotechadv.2011.03.001

Ivanova, A. A., Naumoff, D. G., Miroshnikov, K. K., Liesack, W., and Dedysh, S. N. (2017). Comparative genomics of four isosphaeraceae planctomycetes: a common pool of plasmids and glycoside hydrolase genes shared by Paludisphaera borealis PX4(T), Isosphaera pallida IS1B(T), Singulisphaera acidiphila DSM 18658(T), and Strain SH-PL62. Front. Microbiol. 8:412. doi: $10.3389 /$ fmicb. 2017.00412

Jeske, O., Jogler, M., Petersen, J., Sikorski, J., and Jogler, C. (2013). From genome mining to phenotypic microarrays: planctomycetes as source for novel bioactive molecules. Antonie Van Leeuwenhoek 104, 551-567. doi: 10.1007/s10482-0130007-1

Jeske, O., Surup, F., Ketteniß, M., Rast, P., Förster, B., Jogler, M., et al. (2016). Developing techniques for the utilization of planctomycetes as producers of bioactive molecules. Front. Microbiol. 7:1242. doi: 10.3389/fmicb.2016.01242

Joseph, B., and Sujatha, S. (2010). Pharmacologically important natural products from marine sponges. J. Nat. Products 4, 5-12.

Kolde, R. (2015). Pheatmap: Pretty Heatmaps. R Package Version 1.0. 8.
Invariant sites $(\mathrm{G}+\mathrm{l})$ indicating the relationship of the Planctomycetes strains tested in this work. Bar -0.05 substitutions per 100 nucleotides. The planctomycete Candidatus Scalindua brodae was used as outgroup.

FIGURE S2 | Examples of MOLM-13 cells stained with the DNA binding specific Hoechst dye. (A) Control cells and (B) cells exposed to organic extracts of strain UC49.1. The apoptotic nuclei are bright, condensed or fragmented.

TABLE S1 | Data based on the different degrees of toxicity used for the construction of the heat-map.

Lage, O. M., and Bondoso, J. (2011). Planctomycetes diversity associated with macroalgae. FEMS Microbiol. Ecol. 78, 366-375. doi: 10.1111/j.1574-6941.2011. 01168.x

Lauritzen, S. E., Baastad, L., and Engelien, J. (2018). in Ice Caves. Chapter 23 Norway Fennoscandia and the Arctic, eds A. Persoiu and S. E. Lauritzen (Amsterdam: Elsiever), 479-472.

Liu, L., Herfindal, L., Jokela, J., Shishido, T. K., Wahlsten, M., Døskeland, S. O., et al. (2014). Cyanobacteria from terrestrial and marine sources contain apoptogens able to overcome chemoresistance in acute myeloid leukemia cells. Marine Drugs 12, 2036-2053. doi: 10.3390/md12042036

Matsuo, Y., Macleod, R. A., Uphoff, C. C., Drexler, H. G., Nishizaki, C., Katayama, Y., et al. (1997). Two acute monocytic leukemia (AML-M5a) cell lines (MOLM-13 and MOLM-14) with interclonal phenotypic heterogeneity showing MLL-AF9 fusion resulting from an occult chromosome insertion, ins(11;9)(q23;p22p23). Leukemia 11, 1469-1477. doi: 10.1038/sj.leu.2400768

Oksanen, J., Blanchet, F. G., Kindt, R., Legendre, P., Minchin, P., O’hara, R. B., et al. (2015). vegan: Community Ecology Package. R Package Version 2.2-1.

O’Neill, J. (2016). Tackling Drug-Resistant Infections Globally: Final Report and Recommendations. London: Resistance.

World Health Organization (2012). Non Communicable Diseases - Cancer Data and Statistics. Available at: http://www.euro.who.int/en/health-topics/ noncommunicable-diseases/cancer/data-and-statistics

Ovreås, L., Forney, L., Daae, F. L., and Torsvik, V. (1997). Distribution of bacterioplankton in meromictic Lake Saelenvannet, as determined by denaturing gradient gel electrophoresis of PCR-amplified gene fragments coding for 16S rRNA. Appl. Environ. Microbiol. 63, 3367-3373.

Prestegard, S. K., Oftedal, L., Coyne, R. T., Nygaard, G., Skjærven, K. H., Knutsen, G., et al. (2009). Marine benthic diatoms contain compounds able to induce leukemia cell death and modulate blood platelet activity. Marine Drugs 7, 605-623. doi: 10.3390/md7040605

Quentmeier, H., Reinhardt, J., Zaborski, M., and Drexler, H. G. (2003). FLT3 mutations in acute myeloid leukemia cell lines. Leukemia 17, 120-124. doi: $10.1038 /$ sj.leu. 2402740

Siegel, R. L., Miller, K. D., and Jemal, A. (2017). Cancer statistics, 2017. CA Cancer J. Clin. 67, 7-30. doi: 10.3322/caac.21387

Storesund, J. E., Lanzèn, A., García-Moyano, A., Reysenbach, A.-L., and Øvreås, L. (2018). Diversity patterns and isolation of Planctomycetes associated with metalliferous deposits from hydrothermal vent fields along the Valu Fa Ridge (SW Pacific). Antonie Van Leeuwenhoek 111, 841-858. doi: 10.1007/s10482018-1026-8

Storesund, J. E., and Øvreås, L. (2013). Diversity of Planctomycetes in ironhydroxide deposits from the Arctic Mid Ocean Ridge (AMOR) and description of Bythopirellula goksoyri gen. nov., sp. nov., a novel Planctomycete from deep sea iron-hydroxide deposits. Antonie Van Leeuwenhoek 104, 569-584. doi: 10. 1007/s10482-013-0019-x

Sæbø, E. F. (2018). Isolation and Characterization of Novel Planctomycetes from Svarthammarhola Ice Cave with Potential for Production of Bioactive Molecules. Master thesis, University of Bergen, Bergen.

Tamura, K., Stecher, G., Peterson, D., Filipski, A., and Kumar, S. (2013). MEGA6: molecular evolutionary genetics analysis version 6.0. Mol. Biol. Evol. 30, 27252729. doi: 10.1093/molbev/mst197

Tanaka, Y., Yoshihara, K., Tsuyuki, M., and Kamiya, T. (1994). Apoptosis induced by adenosine in human leukemia HL-60 Cells. Exp. Cell Res. 213, 242-252. doi: 10.1006/excr.1994.1196

R Core Team (2017). R: A Language and Environment for Statistical Computing. Vienna: R Foundation for Statistical Computing. 
Viktorsson, E. Ö, Melling Grøthe, B., Aesoy, R., Sabir, M., Snellingen, S., Prandina, A., et al. (2017). Total synthesis and antileukemic evaluations of the phenazine 5,10-dioxide natural products iodinin, myxin and their derivatives. Bioorg. Med. Chem. 25, 2285-2293. doi: 10.1016/j.bmc.2017. 02.058

Vollmers, J., Frentrup, M., Rast, P., Jogler, C., and Kaster, A.-K. (2017). Untangling genomes of novel planctomycetal and verrucomicrobial species from monterey bay kelp forest metagenomes by refined binning. Front. Microbiol. 8:472. doi: 10.3389/fmicb.2017.00472

Vu, M., Herfindal, L., Juvik, O. J., Vedeler, A., Haavik, S., and Fossen, T. (2016). Toxic aromatic compounds from fruits of Narthecium ossifragum L. Phytochemistry 132, 76-85. doi: 10.1016/j.phytochem.2016. 09.010

Wang, H., Fewer, D. P., Holm, L., Rouhiainen, L., and Sivonen, K. (2014). Atlas of nonribosomal peptide and polyketide biosynthetic pathways reveals common occurrence of nonmodular enzymes. Proc. Natl. Acad. Sci. U.S.A. 111, 9259-9264. doi: 10.1073/pnas.140173 4111

Whitman, W. B., Coleman, D. C., and Wiebe, W. J. (1998). Prokaryotes: the unseen majority. Proc. Natl. Acad. Sci. U.S.A. 95, 6578-6583. doi: 10.1073/pnas.95.12. 6578
Wickham, H. (2009). ggplot2: Elegant Graphics for Data Analysis. New York, NY: Springer-Verlag. doi: 10.1007/978-0-387-98141-3

Yilmaz, P., Parfrey, L. W., Yarza, P., Gerken, J., Pruesse, E., Quast, C., et al. (2014). The SILVA and "All-species Living Tree Project (LTP)" taxonomic frameworks. Opens external link in new window. Nucleic Acids Res. 42, D643-D648. doi: $10.1093 / \mathrm{nar} / \mathrm{gkt} 1209$

Conflict of Interest Statement: The authors declare that the research was conducted in the absence of any commercial or financial relationships that could be construed as a potential conflict of interest.

The reviewer PA declared a shared affiliation, with no collaboration, with several of the authors RC and OL to the handling Editor at the time of review.

Copyright (c) 2019 Calisto, Scebø, Storesund, Øvreås, Herfindal and Lage. This is an open-access article distributed under the terms of the Creative Commons Attribution License (CC BY). The use, distribution or reproduction in other forums is permitted, provided the original author(s) and the copyright owner(s) are credited and that the original publication in this journal is cited, in accordance with accepted academic practice. No use, distribution or reproduction is permitted which does not comply with these terms. 